\title{
Antony And Cleopatra Oyununun Göstergebilimsel Çözümlemesi ve Çeviri Göstergebilimi Bakış Açısıyla Türkçe Çevirilerinin Değerlendirilmesi ${ }^{1},{ }^{2}$ Sündüz ÖZTÜRK KASAR3
} Mesut KULELI 4

\begin{abstract}
Özet
$\mathrm{Bu}$ çalışmanın amacı Shakespeare'in (1950) Antony and Cleopatra oyununu göstergebilimsel açıdan çözümleme ve oyunun Türkçe çevirilerini çeviri göstergebilimi bakış açısıyla değerlendirmektir. Bu amaca yönelik olarak, Shakespeare’in (1950) oyununun özgün metni göstergebilimsel çözümlemede yükümsüz özneleri saptamak için; bu oyunun Adıvar \& Urgan (1949), Eyüboğlu (1967) ve Bozkurt (2002) tarafından yapılan çevirileri ise çeviri değerlendirmesinde veri toplama araçları olarak belirlenmiştir. Özgün metinden elde edilen verilerin göstergebilimsel çözümlemesinde Coquet'nin $(1997,2007)$ öne sürdüğü ve Öztürk Kasar $(2009,2012)$ tarafından çeviri değerlendirmesinde kullanılmak için benimsenen özne odaklı göstergebilim kuramı temel alınmıştır. Çeviri değerlendirmesi için elde edilen veriler Öztürk Kasar'ın (Öztürk Kasar \& Tuna, 2015) Çeviride Anlam Bozucu Eğilimler sınıflandırması temel alınarak çözümlenmiştir. Bulgular, özgün metinde çok sayıda söylemin yükümsüz özne konumundaki söyleyenler tarafından üretildiğini ve bu yükümsüz öznelerin çoğunlukla temel bileşen ve içkin bileşenin etkisi altında söylemlerini ürettiklerini göstermektedir.Ayrica oyunun çevirilerinde yükümsüz özne saptanan 13 söylemde anlam bozucu eğilim bulunmuştur. Öztürk Kasar'ın (Öztürk Kasar \& Tuna, 2015) sınıflandırmasına göre bu 13 söylemin beşinde anlamın bozulması, üçünde anlamın kaydırılması, ikisinde anlamın aşırı yorumlanması, diğer ikisinde anlamın çarpıtılması ve birinde anlamın eksik yorumlanması eğilimleri saptanmıştır. Bu bulgular göstermektedir ki edebi bir eseri çevirmeden önce göstergebilim çözümlemesi yapmak eserin çevirisi esnasında çevirmen için çok yardımcı olmaktadır, göstergebilim çözümlemesi olmaksızın yapılan çevirilerde anlam bozucu eğilimler bulunabilir.
\end{abstract}

Anahtar kelimeler: Yazınsal çeviri, anlam bozucu eğilimler, yükümsüz özne, söyleyenler tipolojisi, söyleyenin bileşenleri

$1 \quad$ Bu makale Yıldız Teknik Üniversitesi Sosyal Bilimler Enstitüsü Diller ve Kültürlerarası Çeviribilim Doktora Programında öğrenci olan Mesut KULELI'nin Prof. Dr. Sündüz ÖZTÜRK KASAR'IN danışmanlığında yazdığı "Çeviri Göstergebilimi Bakış Açısıyla Shakespeare'in Julius Caesar ve Antony and Cleopatra Adlı Oyunlarında Anlam Evreni Göstergeler ve Öznelik Yetisi" başlıklı doktora tezinden üretilmiştir.

$2 \quad$ Bu makalenin Bulgular bölümündeki 3.1. numaralı Göstergebilim Çözümlemesi Sonucu Saptanan Yükümsüz Özneler bölümünden beș adet örnek ve 3.2 numaralı Çeviri Değerlendirmesi sonucu ile ilgili bulgular bölümündeki altı adet örnek 4-7 Haziran 2015 tarihleri arasında Atina'da düzenlenen ERPA konferansında sözlü bildiri olarak sunulmuştur.

3 Prof. Dr., Yıldız Teknik Üniversitesi, Fen Edebiyat Fakültesi, Batı Dilleri ve Edebiyatları Bölümü, Fransızca Mütercim-Tercümanlık Anabilim Dalı, sunduzkasar@hotmail.com

$4 \quad$ Okt., Düzce Üniversitesi, Hakime Erciyas Yabancı Diller Yüksekokulu, mesutkuleli@duzce.edu.tr 
Antony And Cleopatra Oyununun Göstergebilimsel Çözümlemesi ve Çeviri Göstergebilimi Bakış Açısıyla Türkçe Çevirilerinin Değerlendirilmesi / S. Öztürk Kasar - M. Kuleli (98-123. s.)

\title{
Semiological Analysis of the Play 'Anthony and Cleopatra' and Evaluation of Its Turkish Translation Through Semiotics of Translation
}

\begin{abstract}
The aim of this study is to analyze the play Antony and Cleopatra by Shakespeare from a semiotics point of view and evaluate Turkish translations of the play. To this end, the original play by Shakespeare (1950) and three Turkish translations by Adivar \& Urgan (1949), Eyüboğlu (1967) and Bozkurt (2002) have been chosen as data collection tools. Data were obtained from the original play through the instance-oriented semiotics point of view by Coquet $(1997,2007)$, later adopted by Öztürk Kasar in translation analysis. (2009). Data for the translation evaluation were obtained through Öztürk Kasar's (in Öztürk Kasar \& Tuna 2015) classification of Designificative Tendencies in Translation. The findings show that there are quite some non-subjects in the original play. The results of the translation evaluation show that there are 13 discourses with designifactive tendencies in Turkish translations of the play, 5 of them disruption of meaning, 3 of them shift in meaning, 2 of them over-interpretation of meaning and distortion of meaning and eventualy 1 of them under-representation of meaning accordinf to Kasar's (Öztürk Kasar \& Tuna, 2015) Designificative Tendencies typology. This shows that conducting a semiotics analysis before translating a literary work could be instrumental in translating it proficiently while an otherwise situation might lead to designificative tendencies in translation.
\end{abstract}

Key Words: Literary translation, designificative tendencies, non-subject, typology of instances, components of instances

\section{Giriş}

Göstergebilim bir bilim alanı olarak İsviçreli Dilbilimci Ferdinand de Saussure’ün öncülüğü sayesinde son yüzylldır gelişme göstermektedir. Saussure’ün derslerini izleyen öğrencilerine ait ders notlarının Saussure'ün ölümünden üç yıl sonra 1916'da bir araya getirilmesiyle yayınlanan kitabı sayesinde dilbilim ve göstergebilim dünyaya tanıtılmıştır. Saussure (2001 [1916]), bir gün toplumsal hayatta hali hazırda var olan göstergeleri inceleyecek bir bilim alanının kurulacağını, ancak bu bilim alanının dilbilimin bir alt dalı değil, tam aksine dilbilimi de kapsayacak daha geniş kapsamlı bir bilim alanı olacağını öngörmüştür. Saussure (2001) bu bilim alanının isminin göstergebilim (semiology) olmasını önermiştir.

Göstergebilimin bir bilim alanı olarak ortaya çımasını öngören Saussure (2001), göstergebilimin inceleme alanı olan "gösterge" terimini de tanımlayarak bir göstergenin "gösteren" ve "gösterilen" olmak üzere iki unsurdan oluştuğunu ifade ederken, gösteren için "işitim imgesi" terimini, gösterilen için "kavram" terimini önermiş, göstergeleri ortaya çlkaran olgunun bu işitim imgesi ve kavram arasındakibirleşim olduğunu öne sürmüştür. Ayrıca göstergenin özelliklerini açılayan Saussure (2001), göstergelerin "nedensiz" ve "çizgisel" olduğunu, bunun yanı sıra hem zaman içinde süreklilik hem de zaman içinde değişebilirlik niteliklerine sahip olduklarını öne sürmüştür.

Saussure'den sonra çok sayıda kuramsal öncü ve dilbilimci göstergebilime yakın bir ilgi duymuştur, ancak bu çalışma Coquet'nin (1984, 1997, 2007) göstergebilim kuramına dayandırıldığı için bu bölümde yalnızca Coquet'nin göstergebilim kuramının ortaya çlkmasına zemin hazırlayan kuramlar ve Coquet'nin kuramı tartışılacaktır. Öztürk Kasar (2012), Coquet'nin göstergebilim kuramını oluşturmada görüngübilimci Merleau-Ponty'den ve ünlü dilbilimci Emile Benveniste’ten büyük ölçüde etkilendiğini ifade etmiştir, bu yüzden Coquet'nin kuramından önce bu iki kuramcının yaklaşımları hakkında bilgi vermek gerekmektedir. 
Evaluation of Antony and Cleopatra Game of Semiotic Analysis and Translation Turkish Translation Semiotics Perspective / S. Öztürk Kasar - M. Kuleli (p. 98-123)

Primozic (2013), Merleau-Ponty'nin felsefi ve görüngübilim fikirlerini Husserl ve Heidegger etkisi altında geliştirdiğini, ayrıca Descartes’in "beden-zihin” düalizmine ve Descartes felsefesinde zihnin önceliği olgusuna dayanarak ve aynı zamanda buna karşı çıkarak fikirlerini olgunlaştırdığını ifade etmiştir. Rozemond \& Rozemond (2009), Descrates’in felsefesinde, insan algısında beden ve duyuların rolünden ziyade zihne öncelik verdiğini ifade etmiștir. Ancak daha önce belirtildiği gibi Merleau-Ponty (2005) Descartes’in zihne verdiği önceliğe karşı çıkmış ve insanların dış dünyadaki nesnelerin algısına zihin yoluyla değil, öncelikle bedenleri ve duyuları yoluyla ulaşabileceğini, bu yüzden "beden-zihin" düalizminin tam olarak reddedilmesi gerektiğini öne sürmüsstür. Merleau-Ponty (2006) bu görüşünü, zihnimizin etrafımızdaki dış olaylardan etkilendiği, her zaman her yerde kabul gören bir geçerli bir algıya ulaşamayacağı önermesi ile desteklemiştir. Bu görüşlerle Merleau-Ponty (1962) algıda bedenin önceliğine vurgu yaparak kendini görüngübilimin içine sokan "bedenözne" kavramını ortaya atmıștır. Algıda bedenin önceliğini öne sürerek görüngübilim alanına giren Merleau-Ponty, aynı zamanda dil olgusu ile de ilgilenmiştir. Dilin bir görüngübilim bakış açısıyla incelenebileceğini öne süren Merleau-Ponty (1964), dil oluşumu için bedenin öncül koşul olduğunu, algı içinse söylemin önkoşul olduğunu ifade etmiştir. Öyleyse, söylemin ancak beden yoluyla mümkün olduğu düşünüldüğünde, ortaya çıması söyleme bağlı olan algı için de bedenin bir önkoşul olduğu çıkarımına varmak mümkündür ki bu görüngübilimciler tarafindan yaygın bir biçimde kabul edilen bir önermedir. MerleauPonty'nin bedene yaptığı bu vurgu, Coquet'yi göstergebilim kuramını geliştirmede etkilemiş olduğu görünmektedir. .

Dilbilimci Benveniste de, Coquet'nin göstergebilim kuramını geliştirmesinde etkili olmuştur. Benveniste (1995 [1966]), Saussure'ün (2001 [1916])"söz"(parole)terimi yerine "söylem" (discours) ve "sözceleme" (énonciation)terimlerini öne sürmüştür. Saussure (2001 [1916]) söz terimini "bireylerin söylediklerinin toplamıdır ve ... toplumsal bir şey içermez; tüm gerçekleşmeleri bireysel ve bir anlıktır" Saussure'ün söz kavramı yerine söylem kavramını önermiştir ve Öztürk Kasar'a (2012) göre dilbilimde paradigma kaymasına neden olmuştur. Benveniste (1995) bir söylemin olmazsa olmaz unsurlarını "ben, burada ve simdi"olarak ifade etmiștir. Ancak Benveniste (1995) bir söylem içinde öznenin sürekli değiştiğini, dinleyenin söylemi alglladıktan sonra söylem üreticisi olan konuşan durumuna, eski durumda konuşan konumundaki öznenin ise yeni durumda dinleyen konumuna dönüştüğünü ifade etmiştir. Benveniste’e (1995) göre insan kendini ancak dil içinde ve dil yoluyla özne olarak ortaya koyabilir, ayrıca ister psikolojide ister görüngübilimde olsun, öznelik yetisi dilde yatar. Benveniste'in(1995 [1966]) "özne” ve “söylem” terimleri Coquet’yi göstergebilim kuramını geliştirmede etkilemiştir.

Coquet, Paris Göstergebilim Okulu'ndaki çalışma arkadaşı Greimas'tan oldukça farklı bir göstergebilim kuramı geliştirmiştir. Öztük Kasar (2012) Coquet tarafindan Greimas'ın göstergebilim kuramının “nesne göstergebilimi” Coquet'nin göstergebilim kuramının ise "özne göstergebilimi” olarakadlandırıldığını ifade etmiştir. Coquet (1984) kendi kuramını varmış olduğu son aşamasında "söyleyenler kuramı" olarak adlandırmıştır. Coquet (1997; 2007) söyleyenin farklı bileşenlerden oluştuğunu öne sürmüştür. Öztürk Kasar (2012), Coquet'nin “temel bileşen (beden), kavramlaştırıcı bileşen (akul), içkin bileșen (itkiler ve tutkular), aşkm bileșen (kozmik ve simgesel olaylar)" olmak üzere söyleyenin dört bileşenden oluştuğunu öne sürdüğünü ifade etmiştir. Ayrıca Öztürk Kasar (2012) söyleyenin söylem üretimi esnasında farklı bileșenlerin etkisi altında olabileceğini ifade etmiștir. Buna göre, eğer söyleyen söylem üretimi esnasında temel bileşen ve kavramlaştırıcı bileşenin etkisi altında ise bu söylemi bilinçli bir biçimde üretir ve söyleminin sorumluluğunu alabilir ki bu durumdaki söyleyen Coquet'nin (Coquet \& Öztürk Kasar, 2003) söyleyenler tipolojisinde “özne” olarak tanımlanmıştır. Ancak, söyleyen söylem esnasında içkin bileşen veya aşkın 
Antony And Cleopatra Oyununun Göstergebilimsel Çözümlemesi ve Çeviri Göstergebilimi Bakış Açısıyla Türkçe Çevirilerinin Değerlendirilmesi / S. Öztürk Kasar - M. Kuleli (98-123. s.)

bileşenin etkisi altında ise, Coquet'nin (Coquet \& Öztürk Kasar, 2003) söyleyenler tipolojisinde "yükümsüz özne" olarak tanımladığı kategoriye girer. Öztürk Kasar’a (2012) göre yükümsüz özne söylem üretimi esnasında ya bilinçli ya da istemli değildir yahut da ne bilinçli ne de istemlidir; bu durumda söyleminin sorumluluğunu üstlenemez. Coquet'nin (Coquet \& Öztürk Kasar, 2003) söyleyenler tipolojisinde yer alan "eşik-özne" durumundaki söyleyen ise söylem üretimi esnasında etraftaki nesnelerin kısmen bilincinde olan, ancak uyarıcıları tam olarak algılayamayan söyleyendir. Essik-özneye bir örnek olarak Coquet \& Öztürk Kasar'ın (2003) gece yarısı telefon çaldığında uykudan uyanarak telefona cevap veren ancak uyarıcıları ve göstergeleri tam alımlayamayan, söylemini yarı bilinçli bir biçimde üreten söyleyen örneği verilebilir. Bu söyleyenler kuramındaki "yükümsüz özne” ilginç bir önermedir ve Öztürk Kasar (2009) yükümsüz özneyi şu farklı türlere ayırmıştır:

1. Doğa gereği bilinç yokluğu ya da yetersizliği

2. Patolojik bir durumdan kaynaklanan bilinç eksikliği

3. Bazı tedavi amaçlı maddelerin etkisiyle bilinç dışına çıkma

4. Bazı kimyasal maddelerin etkisiyle bilinç dışına çıkma

5. Bedensel dengesizliğe neden olan durumlar

5.1. İtkiler türündeki içkin bileşenden kaynaklanan durumlar

5.2. Tutkular türündeki içkin bileşenden kaynaklanan durumlar

5.2.1. Esenlikli durum

5.2.2. Esenliksiz durum

5.2.3. Coşku kökenli olmayan bedensel dengesizlik durumu

5.3. Kozmik nitelikteki bir aşkın bileşenden kaynaklanan bedensel dengesizlik durumu

6. Aşkın bir bileşene boyun eğme durumu

6.1. Az ya da çok içselleştirilmiş sembolik nitelikte bir aşkın bileşene boyun eğme

6.2. Korku salan ya da işkence eden baskın nitelikte bir aşkın bileşene boyun eğme

6.3. Söyleyenin iradesi üzerine etki eden bir bileşene boyun eğmesi

7. Robotlaş(tırıl)mış özne

8. Bir işleve indirgenmiş kimlik: biçim-özne ${ }^{6}$

6 Öztürk Kasar, S. (2009) «Pour une typologie des non-sujets: au carrefour de la sémiotique et de la phénoménologie. »Sémio 2007: Rencontres sémiotiques: les interfaces disciplinaires, des théories aux pratiques professionnelles. Actes duCongrès international de l'Association Française de Sémiotique, Paris: Université Paris IV La Sorbonne. http://afssemio.com/semio2007/spip.php?article19. s. 3-6 
102/ RumeliDE Journal of Language and Literature Studies 2016.5 (April)

Evaluation of Antony and Cleopatra Game of Semiotic Analysis and Translation Turkish Translation Semiotics Perspective / S. Öztürk Kasar - M. Kuleli (p. 98-123)

\section{Yöntem}

$\mathrm{Bu}$ bölümde, veri toplama araçları, veri toplama yöntemi ve veri çözümleme yöntemi sunulacaktır.

\subsection{Veri toplama araçları}

Bu çalışmada Cambridge Yayınevi tarafindan yayımlanan Shakespeare'in (1950) Antony and Cleopatra özgün metni oyunun göstergebilimsel çözümlemesi için kullanılmıştır. Çeviri göstergebilimi bakış açısıyla oyunun çeviri değerlendirmesi için Shakespeare’in bu eserinin Adıvar \& Urgan (1949), Eyüboğlu (1967) ve Bozkurt (2002) tarafından yapılan Türkçe çevirileri kullanılmıştır. Karantay (1995) bir oyunun sadece sahnelenmek için değil, aynı zamanda edebi bir değere sahip bir metin olarak da ele alınabileceğini ve buna yönelik olarak çevrilebileceğini ifade etmiştir.Bu yüzden bu çalışmada Shakespeare'in Antony and Cleopatra oyunu sadece edebi olarak ele alınmış ve çevirileri bu düzeyde değerlendirilmiştir.

\subsection{Veri toplama yöntemi}

Veri toplama amaciyla Shakespeare'in (1950) özgün metninde göstergebilimsel çözümleme yapmak için Coquet'nin (1997) çeviri ediminde uygulanması için Öztürk Kasar (2012) tarafından benimsenen "söyleyenin bileşenleri" kuramı ve Coquet'nin (Coquet \& Öztürk Kasar, 2003) "söyleyenler tipolojisi” kuramı temel alınmıştır. Söyleyenler tipolojisindeki yükümsüz özneleri bu çalışmadaki oyunda saptayabilmek için Öztürk Kasar'ın (2009) örneklemeli “yükümsüz özneler tipolojisi” kullanılmıştır. Çeviri değerlendirmesinde, oyunun üç Türkçe çevirisi özgün metinde elde edilen göstergebilimsel çözümleme ışığında sadece yükümsüz öznelerin bulunduğu .. söylemler bakımından çözümlenmiş ve çeviri değerlendirmesi Öztürk Kasar'nn (Öztürk Kasar \& Tuna, 2015) “çeviride anlam bozucu eğilimler" sınıflandırması temel alınarak yapılmıştır.

\subsection{Veri çözümleme}

Veri çözümleme nitel yöntem ile yapılmıştır. Özgün metinden elde edilen veriler sadece İngilizcesine bakılarak çözümlenmiştir. Bu ç̧özümlemede söylem esnasında söyleyenin üzerinde etkili olan bileşenler saptanmış ve Öztürk Kasar'ın (2009) Coquet'nin yükümsüz özne kavramını örneklendirdiği yükümsüz özneler tipolojisine dayanarak söylem üreticisinin hangi yükümsüz özne kategorisinde olduğu belirlenmiştir. Çeviri değerlendirmesinde, üç çevirinin tümünde yükümsüz özne içeren söylemler Öztürk Kasar’ın (Öztürk Kasar \& Tuna, 2015) çeviride anlam bozucu eğilimler sınıflandırması temel alınarak söylemlerin hangi çevirmen tarafından ve hangi anlam bozucu eğilim kullanılarak çevrildiği bulunmuştur. Ôztürk Kasar (Öztürk Kasar \& Tuna, 2015) çeviride dokuz anlam bozucu eğilim belirlemiş ve bu eğilimleri şöyle sinıflandırmıştır:

1. Anlamın aşırı yorumlanması: Özgün yapıtta örtük olan bir anlamı görünür biçimde dile getirmek.

2. Anlamın bulanıklaştııılması: Özgün yapıtta açık seçik bir biçimde dile getirilmiş bir anlamı bulanık, belirsiz hale getirmek.

3. Anlamın eksik yorumlanması: Eksik bilgi vermek, yetersiz anlam üretmek.

4. Anlamın kaydırılması: Bir söz biriminin potansiyel olarak içinde taşıdığı ancak özgün metin bağlamında gerçekleşmemiş olan bir anlamı üretmek ya da özgün metnin çağrıştırmadığı bir yananlam yaratmak. 
5. Anlamın bozulması: Özgün metindeki anlamla tümüyle ilintisiz olmamakla birlikte yanlış olan bir anlam üretmek.

6. Anlamın çarpıtılması: Özgün metindeki anlama zıt bir anlam üretmek.

7. Anlamın saptırılması: Özgün metindeki anlamla hiçbir ilintisi olmayan bir anlam üretmek.

8. Anlamın parçalanması: Anlamdan yoksun bir sözce üretmek.

9. Anlamın yok edilmesi: Özgün birimde anlam üreten birimin silinmesi, yok edilmesi.7

\section{Bulgular}

Bu bölüm, özgün metindeki göstergebilimsel çözümleme sonucunda elde edilen yükümsüz özne içeren söylemlerin ve çeviri değerlendirmesi sonucunda elde edilen çeviride anlam bozucu eğilimlerin saptandığı söylemlerin bulunduğu iki alt bölüm olarak sunulmuştur.

\subsection{Göstergebilim çözümlemesi sonucu saptanan yükümsüz özneler}

Göstergebilimsel çözümleme sonucunda oyunda çok sayıda yükümsüz özne içeren söylemler bulunmuştur. Bu yükümsüz öznelerin çoğunluğu temel bileşen ve tutkular türündeki içkin bileşenin etkisi altında söylem üreticileridir. Saptanan yükümsüz öznelere dair seçilen örnekler şunlardır:

Örnek 1:

Antonius:

Let Rome in Tiber melt and the wide arch

Of the ranged empire fall. Here is my space. (s. 4)

Bu söylemin üreticisi olan Antonius söylem üretiminde tutku kaynaklı içkin bileşen ve temel bileşenin etkisi altında söylemini gerçekleştirmiştir. Büyük bir asker ve savaş adamı olarak bilinen Antonius'un aşkı Kleopatra uğruna Roma'yı gözden çıkarmış olması yükümsüz özne olduğunu göstermektedir. Antonius bu söylemiyle Öztürk Kasar’n (2009) tipolojisinde tutkular türündeki içkin bileşenden kaynaklı esenlikli durum ile ortaya çıkan yükümsüz özne olarak saptanmıştır.

Örnek 2:

Mark Antony

Hark! the land bids me tread no more upon't;

It is ashamed to bear me! Friends, come hither:

I am so lated in the world, that I

7 Öztürk Kasar, S., Tuna, D. (2015). «Yaşam, Yazın ve Yazın Çevirisi İçin Gösterge Okuma», Frankofoni Ortak Kitap, no: 27, Ankara, 457-482. s. 463 
Evaluation of Antony and Cleopatra Game of Semiotic Analysis and Translation Turkish Translation Semiotics Perspective / S. Öztürk Kasar - M. Kuleli (p. 98-123)

Have lost my way for ever: I have a ship

Laden with gold; take that, divide it; fly,

And make your peace with Caesar. (s.70)

Bu söylemde Antonius kaybettiği savaş sonrası büyük bir elem ve Kleopatra'ya savaştan kaçtı̆̆ için büyük bir kızgınlık içindedir. Adamlarına seslendiği bu söylemde kavramlaştırıcı bileşenden uzaklaşan Antonius, temel bileşen ve tutku güdümlü içkin bileşenin kontrolü altındadır. Öztürk Kasar'ın (2009) sınıflandırmasına göre tutkular türündeki içkin bileşenden kaynaklanan esenliksiz durum içinde olan Antonius bu söylemin üretiminde yükümsüz özneye dönüşmüştür.

Örnek 3:

$$
\begin{aligned}
& \text { Mark Antony } \\
& \text { No, no, no, no, no. } \\
& \text { Eros } \\
& \text { See you here, sir? } \\
& \text { Mark Antony } \\
& \text { O fie, fie, fie! (s. 71) }
\end{aligned}
$$

Savaşı kaybetmenin verdiği elemle yükümsüz özneye dönüşen ve yargı kabiliyetini kaybeden Antonius temel bileşen ve tutku güdümlü içkin bileşenin etkisinde Öztürk Kasar'ın (2009) sınıflandırmasına göre robotlaşmış özneye dönüşmüştür. Öztürk Kasar (2009) robotlaşmış öznenin sürekli papağan gibi kendini tekrarladığını ifade etmiştir. Bu söylemde Antonius savaş sonrası değerlendirmesini yapamayacak kadar elem içine girerek sürekli aynı sözcüğü tekrarlayarak robotlaşmış özne olarak saptanmış ve yükümsüz özneye dönüşmüştür.

Örnek 4:

Cleopatra

O my lord, my lord,

Forgive my fearful sails! I little thought

You would have follow'd.

Mark Antony

Egypt, thou knew'st too well

My heart was to thy rudder tied by the strings,

And thou shouldst tow me after: o'er my spirit 
Antony And Cleopatra Oyununun Göstergebilimsel Çözümlemesi ve Çeviri Göstergebilimi Bakış Açısıyla Türkçe Çevirilerinin Değerlendirilmesi / S. Öztürk Kasar - M. Kuleli (98-123. s.)

Thy full supremacy thou knew'st, and that

Thy beck might from the bidding of the gods

Command me.

Cleopatra

O, my pardon!

Pardon, pardon!

Mark Antony

Fall not a tear, I say; one of them rates

All that is won and lost: give me a kiss;

Even this repays me. (s. 72)

Antonius'un savaşı kaybetmesine sebep olan Kleopatra, savaş sonrası Antonius ile ilk karşılaşmasında korkudan dolayı temel bileşen ve tutku güdümlü içkin bileşenin etkisi altında ürettiği söyleminde korku salan baskın nitelikte bir aşkın bileşene boyun eğme durumunda yükümsüz özneye dönüşmüss ve hep aynı sözü "pardon” (bağışla beni) papağan gibi tekrarlayarak aynı zamanda Öztürk Kasar'ın (2009) sınıflandırmasına göre robotlaşmış özne durumuna dönüssmüsstür. Bu söylemde yükümsüz özne olan tek söylem üreticisi Kleopatra değildir, büyük bir komutan olarak ün yapmış olan Antonius da "Fall not a tear, I say;one of them rates / All that is won and lost: give me a kiss" (Ağlama sakın, bir damla gözyaşın senin/ Kazanıp yitirdiğim her şeyden üstündür./ Bir kez öp beni)söylemiyle temel bileşen ve tutku güdümündeki içkin bileșenin etkisi altında esenlikli durumda yükümsüz özneye dönüşmüsstür. Julius Caesar oyununda, kendini ülkesine ve insanlarına adamış olan ve bu uğurda aylarca dağlarda kalarak hayvan leşi ile beslendiği ifade edilen Antonius'un bu söylemde tüm komutanlık özelliklerini bir kenara atarak irade dışında bu söylemi ürettiği ve yükümsüz özneye dönüşmüş olduğu düşünülmektedir zira büyük bir asker olarak ün salmış bir komutanın aşkı uğruna tüm ülkesini gözden çıkarması söz konusudur. Antony and Cleopatra oyununda da Philo, Antonius'un durumunu göstermek için şu söylemi üretmiştir:

His captain's heart,

Which in the scuffles of great fights hath burst

The buckles on his breast, reneges all temper

And is become the bellows and the fan

To cool a gypsy's lust. (s. 3)

Bu söylemde geçen "scuffles of great fights hath burst / the buckles on his breast... the fan / to cool a gypsy's lust" ( büyük savaşlarda göğsündeki zırhları gevşeten 
[Antonius]... / Mısırlı bir çingenenin sevgisini soğutmak için yelpaze oldu) ${ }^{8}$ cümlesi de Antonius'un mevcut söylemde yükümsüz özneye dönüştüğünü doğrulamaktadır.

Örnek 5:

Scarus

We'll beat 'em into bench-holes. I have yet

Room for six scotches more. (s. 90)

Bu söylemde Scarus, çözümlemede ilk defa karşımıza çıkan bir yükümsüz özne durumuna geçmiştir. Kavramlaştırıcı bileşenden tamamen soyutlanmış bu söylemde temel bileşen ve içkin bileşen rol oynamaktadır. Öztürk Kasar (2009) yükümsüz öznenin en basit örneği olarak temel bileşen ve içkin bileşenin birlikte rol oynadığı söylemi üreten özneye işaret etmiştir. Kendini Antonius'a adamış olan Scarus, Öztürk Kasar'ın (2009) sinıflandırmasına göre bir işleve indirgenmiş biçim-özne durumunda yükümsüz özne olarak karşımıza çıkmaktadır. Öztürk Kasar'a (2009) göre bireysel biçim-özneler kendilerine seçtikleri bir ülkü uğruna her şeyden vazgeçerler. Scarus da bu söylemde savaşta yaralanmış olmasına rağmen ölümüne bu savaşa devam edeceğini söyleyerek yükümsüz özneye dönüştüğünü açı̆̆a vurmaktadır.

Örnek 6:
Mark Antony
I am dying, Egypt, dying; only
I here importune death awhile, until
Of many thousand kisses the poor last

I lay upon thy lips. (s. 103)

Antonius bu söyleminde kendini kılıcın üstüne bıraktığı için aldığı yaradan ölmek üzeredir ve artık dış dünyayı da alımlayamaz duruma gelmiştir. Bu yüzden bu söyleminde temel bileşenin de kavramlaştırıcı bileşen gibi devre dışı kaldığını, sadece tutku güdümlü içkin bileşenin rol oynadığını. çıkarmak mümkün olabilir. Temel bileşenin dahi devre dışı kalması sebebiyle bu söylemde Öztürk Kasar'ın (2009) sinıflandırmasına göre Antonius'untravmatik bir durumdan kaynaklanan bilinç eksikliği durumunda yükümsüz özneye dönüştüğü sonucuna varılabilir.

Örnek 7:

Cleopatra

Why, that's the way

To fool their preparation, and to conquer

Their most absurd intents. 
Antony And Cleopatra Oyununun Göstergebilimsel Çözümlemesi ve Çeviri Göstergebilimi Bakış Açısıyla Türkçe Çevirilerinin Değerlendirilmesi / S. Öztürk Kasar - M. Kuleli (98-123. s.)

\author{
CHARMIAN returns \\ Now, Charmian! \\ Show me, my women, like a queen: go fetch \\ My best attires: I am again for Cydnus, \\ To meet Mark Antony. Sirrah Iras, go. (s. 118)
}

Kleopatra bu söylemle birlikte ölüm isteğini tam olarak aşikâr etmiştir. Caesar'ın onu Roma'da halka esir gibi göstermesindense ölümü yeğleyen Kleopatra, hem bu durumdan kurtulmak hem de sevgilisi Antonius ile bulușabilmek için ölümü seçer ve buna ulașmak için elinden gelen her şeyi yapmaya hazırdır. Mevcut söylemde Shakespeare aynı zamanda metinlerarası bir gönderge de yaparak Tarsus'taki Cydnus nehrini Kleopatra'nın söyleminin içine dâhil eder, böylece okur ölmüș olan Antonius ile buluşmak isteyen Kleopatra'nın kötü bir üne sahip olan Cydnus nehrini söylemine dâhil etmesinden dolayı Kleopatra'nın intihar isteğini alımlayabilir. Ölüm ile bağdaştırılan bu nehir söyleme dâhil edilerek intihar eğilimi açığa çıkarılmıştır. Bu söylemde Kleopatra'nın yükümsüz özne olarak söylem üreticisi olduğu ifade edilebilir. Bu söylem üretiminde Coquet'nin sınıflandırmasına göre temel bileşen ve tutku güdümlü içkin bileşenin etkisi olduğu ifade edilebilir.

\title{
3.2. Çeviri değerlendirmesi sonucu elde edilen bulgular
}

Öztürk Kasar'ın (Öztürk Kasar \& Tuna, 2015) çeviride anlam bozucu eğilimler sınıflandırmasına dayanarak elde edilen çeviri değerlendirmesi bulgularına göre oyunun çözümlenen üç Türkçe çevirisinin hepsinde anlam bozucu eğilimler bulunmuştur. Oyunda saptadığımız 13 anlam bozucu eğilim şunlardır:

Örnek 1:

Antony

He fell upon me, ere admitted, then:

Three kings I had newly feasted and did want

Of what I was i'th'morning: (s. 27)

Antonius

- O haberci izin almadan içeri dalmıştı.

Bir gece önce üç krala ziyafet vermiştim

Ve sabah daha kendimde değildim. Bozkurt, B. (2002) s. 59

Ant- Efendim, müsaademi almadan huzuruma gelmişti. O sırada üç krala ziyafet veriyordum. Sabahları olduğum kadar soğukkanlı değildim. Edib-Adıvar, H. \& Urgan, M.

(1949) s. 33 
Evaluation of Antony and Cleopatra Game of Semiotic Analysis and Translation Turkish Translation Semiotics Perspective / S. Öztürk Kasar - M. Kuleli (p. 98-123)

Verilen her iki çeviri eserde de Öztürk Kasar'ın (Öztürk Kasar \& Tuna 2015) sınıflandırmasına göre anlamın bozulması söz konusu olmuştur. Özgün eserdeki "Three kings I had newly feasted" sözcesi Edib-Adıvar, H. \& Urgan, M. (1949) tarafindan "O sirada üç krala ziyafet veriyordum" diye çevrilerek özgün metindeki anlam ile ilintili fakat yanlış bir anlam yakalanmasina neden olmuştur. Özgün eserdeki "had newly feasted" ifadesi "past perfect tense" olarak geçmektedir ve bu geçmiște yaşanılan iki olaydan önce olan olayı anlatan bir zamandır, dolayısıyla olaylar arasında es anlılık değil öncelik-sonralık ilișkisi gerektirmektedir. $\mathrm{Bu}$ çeviride ise bir eş zamanlılık söz konusu olarak yanlış anlam üretilmiştir. Bozkurt'un (2002) çevirisinde söz konusu olan yer "üç krala ziyafet vermiştim" diye çevrilerek bu ziyafetin daha önce bitmiş olduğu anlamı yakalanmıștır, fakat özgün eserde yer alan "and did want / Of what I was i'th'morning" söylemi bu çeviride "Ve sabah daha kendimde değildim" diyerek çevrilerek yine özgün metinle ilintili fakat yanlış bir anlam yakalanmıștır zira özgün eserdeki "Of what I was i'th'morning” söylemi bir kıyaslama gerektirir ve zamansal olarak sabah değil muhtemelen şölenin daha yeni bittiği bir gece yarısından bahsediliyor. Diğer çeviride ise şu söylem üretilmiştir:

Antonius

Bak ne oldu, Caesar; izin almadan çıktı karşıma.

Üç krala ziyafet vermiştim o gün,

Sabahki aklım yoktu başımda. Eyüboğlu (1967) s. 48-49

$\mathrm{Bu}$ çeviride hem İngilizcedeki past perfect tense'in gerektirdiği öncelik sonralık ilişkisi yakalanmış hem de "Sabahki aklım yoktu başımda." söylemi ile kıyaslama yapılabilmiştir.

Örnek 2:

\section{LEPIDUS}

Nay, certainly, I have heard the Ptolemies'

pyramises are very goodly things; without

contradiction, I have heard that. (s. 47)

$\mathrm{Bu}$ söylemde "Ptolemies" göndergesi okuru uyararak metinlerarası bir ilişki olduğunu göstermektedir. Bozkurt'un (2002) çeviride bu söylem için verdiği dipnotta I.ve II. Ptolemeusların Mısır hükümdarı olduğu ifade edilmektedir. Fakat bu söylemde okuru harekete geçiren en önemli gösterge "pyramises" kelimesidir. Mısır hükümdarları ve "pyramises" göstergesi aynı bağlamda kullanıldığında okur "piramitler” göstergesini düşünmektedir. Bu söylemi tam yorumlayabilmek için söylemin oluştuğu şartları belirlemek gereklidir. Antonius-Caesar-Lepidus üçlüsü Sextus Pompeius ile savaş için karşlaştıklarında hiç savaş yapmaksızın konuşarak anlaşmışlardır ve bunu Pompeius'un gemisinde kutlamak için toplanırlar. Bu kutlamada bol miktarda şarap içilmiştir ve Lepidus o kadar çok içmiştir ki gemideki diğerlerinin söylemlerinden Lepidus'un ayakta bile zor durduğu anlaşılmaktadır. Alkolün etkisi altında sarhoş olmuşken ürettiği bu cümlede dili sürçtüğü için "pyramids" yerine "pyramises" demiş olabilir. Lepidus söylediği cümlede kendinde olmadığ 1 için "certainly (kesin bir şekilde), without contradiction (hiç şüphesiz ki) gibi oyunun başka hiçbir yerinde aklı başındayken bu kadar kesinlik ifade eden ifadeleri kullanmamışken bu söylemde kullanmıștır. Bu yorum Bozkurt'un (2002) verdiği dipnotta da desteklenmektedir. Ayrıca Bozkurt (2002) bu dipnotta Ptolemeusların piramit inşa ettirmediğini, sadece tapınak inşa 
Antony And Cleopatra Oyununun Göstergebilimsel Çözümlemesi ve Çeviri Göstergebilimi Bakış Açısıyla Türkçe Çevirilerinin Değerlendirilmesi / S. Öztürk Kasar - M. Kuleli (98-123. s.)

ettirdiğini, Shakespeare'in yanlışlıkla veya bilgi eksikliği ile bu cümleyi kurmuş olabileceğini ifade etmiştir. Ancak bizim yorumumuz, Lepidus çok sarhoş olduğu için Shakespeare tarafından özellikle ona bu cümle kurdurtularak hem yanlış bilgi hem de dil sürçmesi yaptırılmış olabilir. Özgün metin okuru Lepidus'un sarhoşluğu sebebiyle bu cümlede yanlış bilgi verdiğini ve dil sürçmesi yaşadığını alımlayabilir, bu durum çeviri metin okuruna da yansitılmalıdır. Bozkurt’un (2002) çevirisi şöyledir:

\section{LEPIDUS}

Hayır, gerçekten duyduğuma göre Ptolemeus'ların piramisleri muazzam şeylermiş. İnanın, kesin duydum bunu. (Bozkurt, 2002) s. 92

$\mathrm{Bu}$ çeviride hem "Ptolemeus" göndergesi korunarak, hem de dil sürçmesi yaşanan "pyramises" göstergesi "piramisler" diye çevrilerek ve yanlış bilgi aynı şekilde aktarılarak çeviri metin okurunun Lepidus'un sarhoş olduğu için yükümsüz özneye dönüştügünü̈ alımlaması sağlanmıştır, bu yüzden bu çeviride herhangi bir anlam bozucu eğilim bulunmamaktadır. Ancak Edib-Adıvar \& Urgan (1949) ve Eyüboğlu’nun çevirileri şöyledir:

\section{LEPIDUS}

Ya! Sahiden işittim ki, Batlamius'ların ehramları pek yaman şeylermiş! Bunun şüphesi yok, kendim işittim. (Edib-Adıvar \& Urgan, 1949) s. 57

\section{LEPIDUS}

Ha, sahi, duyduğuma göre Batlamius'ların ehramları pek yaman şeylermiş. Martaval değil, kulaklarımla duydum bunu. (Eyüboğlu, 1967) s. 84

Bu iki çeviride hem Edib-Adıvar \& Urgan (1949) hem de Eyüboğlu (1967) özgün eserdeki "pyramises” göstergesini “ehram” kelimesi ile Türkçeye aktarmışlardır. Türk Dil Kurumu'nun online sözlüğünde "ehram" kelimesi için "Piramit”9 karşılığı çıkmaktadır. Ayrıca bu sözlükte bu kelimenin Tarih ve Matematik alanlarında kullanıldığı, Arapçadan dilimize geçen bir kelime olduğu ifade edilmektedir. Çevirilerin yapıldı̆̆ı tarihleri düşündüğümüzde, EdibAdıvar \& Urgan'ın çevirileri 1949 yılında, Eyüboğlu'nun çevirisi ise 1967 yllında yayımlanmıştır. 1949 yılında Arapça kelimelerin dilimizde daha yaygın olduğu, 1967 yılında da Arapça kelimelerin halen halk tarafından kullanılıyor olduğu varsayımına varılabilir. Ancak "ehram" kelimesinin kullanımında sarhoş bir insanın dilinin sürçmesi söz konusu değildir, kelime doğru şekilde yazılıp kullanılmıştır. Bu iki çeviride çevirmenler "pyramises” kelimesinin aslında "pyramids" olduğunu anlayarak ve kendi yorumlarını katarak Türkçesini doğru bir şekilde yazmıș, ancak bu durumda Shakespeare’in amaçlamış olabileceği sarhoş bir insanın konuşmasında dilinin dolanması ve sürçmesi çeviri eser okuruna aktarılmamıştır. Bir insanın sarhoş olduğunu hareketlerinden ve özellikle dilinin dolanması ve kelimelerin doğru söyleyememesinden anlarız. Edebi eser okuru Lepidus'un hareketlerinden ziyade konuşmasıyla onun sarhoş olduğunu anlayabilir ancak bu çevirilerde herhangi bir dil sürçmesi olmamasından dolayı okur Lepidus'un sarhoş olduğunu anlayamaz ve bu yüzden tarihi olarak yanlış bir bilgi verdiğini de alımlayamaz. Bu anlam bozucu eğilim Öztürk Kasar'ın (Öztürk Kasar \& Tuna 2015) sınıflandırmasındaki anlamın eksik yorumlanmasına örnek olarak gösterilebilir.

\footnotetext{
9 http://tdk.gov.tr/index.php?option=com_gts\&arama=gts\&guid=TDK.GTS.5656eaa3b40f19.99706079 Erişim tarihi: 25.11.2015
} 
Evaluation of Antony and Cleopatra Game of Semiotic Analysis and Translation Turkish Translation Semiotics Perspective / S. Öztürk Kasar - M. Kuleli (p. 98-123)

\section{Örnek 3:}

Antony

Her tongue will not obey her heart, nor can

Her heart inform her tongue. (s. 55)

\section{Antonius}

Ya dili çaresiz anlatamıyor yürekten geleni;

Ya yüreği çaresiz, bilemiyor,

Nasıl iletsin duygularını dile. (Bozkurt, 2002) s. 105

Bu söylemde özgün metinde yer alan "not ..... nor" kalıbı "ne ..... ne de" olarak Türkçeye çevrilmesi gereken bir sözbirim iken, çevirmen tarafından nerdeyse tam tersi bir anlamla "ya ....ya da" anlamında çevrilmiştir. Bu durum, Öztürk Kasar'ın (Öztürk Kasar \& Tuna 2015) sınıflandırmasına göre karşıt bir anlam üretilerek anlamın çarpıtılması eğilimine örnek gösterilebilir. "Ne .... ne de" kalıbında herhangi bir seçenek yokken, İngilizcede "either....or" diye var olan seçenek ve alternatif bildirme durumu ise tam zit bir anlam katmaktadır. $\mathrm{Bu}$ söylemin diğer çevirmenler tarafindan çevirisi şöyle yapılmıştır:

Antonius

Ne dili yüreğinin buyruğuna girebilir şimdi

Ne yüreği diline dert anlatabilir. (Eyüboğlu, 1967) s. 99

Ant - Ne dili gönlüne uyuyor, ne gönlü diline söyleyeceğini öğretebiliyor. (Edib-Adıvar \& Urgan, 1949) s. 67

Görüldüğü gibi diğer iki çeviride "not .....nor" kalıbı doğru "ne ...... ne de" olarak Türkçeye aktarılmıştır ve herhangi bir anlam bozucu eğilim görülmemektedir.

Örnek 4:

Agrippa

He has a cloud in's face.

Enobarbus

He were the worse for that, were he

a horse;

So is he, being a man. (s. 55) 
Antony And Cleopatra Oyununun Göstergebilimsel Çözümlemesi ve Çeviri Göstergebilimi Bakış Açısıyla Türkçe Çevirilerinin Değerlendirilmesi / S. Öztürk Kasar - M. Kuleli (98-123. s.)

\begin{abstract}
Agrippa
Yüzü gölgelendi.

Enobarbus

At olsaydı bu yüzden kıymetini kaybederdi. Erkekler için de böyle ya! (Edib-Adıvar \& Urgan, 1949) s. 67
\end{abstract}

Bu söylemde özgün eserde geçen "were he a horse;" "at olsaydı" ifadesinden sonra "So is he, being a man.” ifadesindeki "man" sözcüğü "Erkekler için de böyle ya!" olarak çevrilmiştir. Cambridge Online Sözlüğe başvurduğumuzda "man" sözcüğü için iki anlam bulunmaktadır, bunlar "adam" "ademoğlu, insanoğlu" o olarak karşımıza çlkmaktadır. Bu söylemde "at olsaydı" ifadesinden sonra "erkekler için de böyle" denilmesi söylemde anlamın kaydırılmasına bir örnek olarak düşünülebilir zira "at" ile "erkekler" kıyaslanmasından ziyade "at" ile "insanlar"ın duygularının karşılaştırılması daha uygun olabilmektedir, dolayısıyla sözbirimin potansiyel anlamlarından biri kullanılmış olsa da özgün metinde bu anlam geçerli olmadığ 1 için bu söylemin çevirisinde Öztürk Kasar'ın (Öztürk Kasar \& Tuna 2015) sınıflandırmasına göre anlamın kaydırılması eğilimi bulunmuştur. Diğer iki çeviriye bakıldığında;

\title{
Agrippa
}

Böyle bir yüz atlarda bile iyiye yorulmaz,

İnsanda oldu mu büsbütün kötü. (Eyüboğlu, 1967) s. 99

\author{
Agrippa \\ Yüzünde kara bulut var. \\ Caesar at olsa uğursuz sayllırdı, \\ Neyse ki insan. (Bozkurt, 2009) s. 105
}

Bu iki çeviride "man" göstergesi "insan" olarak çevrilmiş ve hayvanları temsilen konulan at ile erkeklerin duygularını kıyaslamaktan ziyade at ile insanın duyguları kıyaslanarak sözbirimin potansiyel anlamlarından özgün eserdeki söyleme uygun olan anlam kullanılmıştır. Bu yüzden bu iki çeviride man" göstergesinin Türkçeye taşınmasında herhangi bir anlam bozucu eğilim görülmemektedir.

Örnek 5:

ANTONY

Leave me, I pray, a little: pray you now,

10 http://dictionary.cambridge.org/dictionary/turkish/man_1. Erişim tarihi: 08.12. 2015 
Evaluation of Antony and Cleopatra Game of Semiotic Analysis and Translation Turkish Translation Semiotics Perspective / S. Öztürk Kasar - M. Kuleli (p. 98-123)

Nay, do so; for indeed I have lost command,
Therefore I pray you: I'll see you by and by. (s.70-71)

ANTONIUS

Hadi, gidin şimdi lütfen;

Kendimde değilim şu anda.

Hadi, lütfen, birazdan görüşürüz. (Bozkurt, 2002) s. 130

Antonius'un esenliksiz durumdan kaynaklanan yükümsüz özne olduğu bu söylemdeki "I have lost command" cümlesi yükümsüz özne olduğunu kanıtlamaktadır. Bu cümledeki "command" göstergesi Cambridge çevrimiçi sözlük tarafından hem askerlik terimi olan "komuta" anlamılla hem de "yetkinlik" ${ }^{11}$ karşılıkları ile verilmiştir. Bu söylemdeki "command" kelimesi askerlik terimi olmaktan ziyade yaptıklarının farkında olma, hakimiyet anlamına daha yakındır zira bu söylemde Antonius kendi askerlerine ve adamlarına seslenmektedir ve askerlik şerefini bir tarafa bırakmış, sadece Kleopatra'ya olan aşkı yüzünden her şeyini kaybetmiş olan bir insan olarak adamlarına seslenmektedir. Ancak bu seslenmede etrafındaki kişiler askerleri olduğu için ve daha sonra yine onlara emirler vereceği için "lost command" göstergesini bir kumandan olarak "emir verme yetkisini kaybetmek" anlamında kullanmış olması olası gözükmemektedir. Ayrıca kaybettiği savaşlardan daha da kötüsü Kleopatra'nın ona ihanet etmesi yüzünden acı çekmektedir ve çok da fazla askerlik şerefini düşünebilecek durumda değildir bu söylemin üretiminde. Bozkurt (2002) bu cümleyi "kendimde değilim şu anda" şeklinde çevirerek herhangi bir anlam bozucu eğilim göstermemiştir. Bu söylemin Eyüboğlu (1967) ve Edib-Adıvar \& Urgan (1949) tarafından çevirisi şöyle yapılmıştır:

\section{ANTONIUS}

Bırakın beni, ne olur, biraz yalnız bırakın beni.

Haydi, yalvarırım size; ne olur, yapın dediğimi;

Komutan değilim artık ben, değilim gerçekten;

Onun için dinleyin beni: gün gelir görüşürüz yine. (Eyüboğlu, 1967) s. 125

\section{ANTONIUS}

Haydi rica ederim bırakın beni. Hakikaten kumandanlığı kaybettim, onun için rica ediyorum. Sizi birazdan görürüm. (Edib-Adıvar \& Urgan, 1949) s. 86

Özgün eserdeki "I have lost command" cümlesini Eyüboğlu (1967) "komutan değilim artık ben" şeklinde çevirirken Edib-Adıvar \& Urgan (1949) "kumandanlığımı kaybettim" şeklinde çevirmiştir. Bu çevirilerdeki "komutan" ve "kumandan" kelimeleri her ne kadar "command" göstergesinin muhtemel anlamları arasında olsa da özgün eserdeki bağlamda bu anlamı dışında kullanılmıştır. Dolayısıyla Eyüboğlu (1967) ve Edib-Adıvar \& Urgan (1949) göstergenin bu bağlama uymayan anlamlarından birini kullanarak bu söylemi çevirdikleri için Oztürk Kasar'ın (Öztürk Kasar \& Tuna 2015) sınıflandırmasına göre anlamın kaydırılması anlam bozucu eğilimi vardır.

11 http://dictionary.cambridge.org/dictionary/turkish/command_1 Erişim tarihi: 20.12.2015 
Antony And Cleopatra Oyununun Göstergebilimsel Çözümlemesi ve Çeviri Göstergebilimi Bakış Açısıyla Türkçe Çevirilerinin Değerlendirilmesi / S. Öztürk Kasar - M. Kuleli (98-123. s.)

Örnek 6:

Antony

Approach, there! Ah, you kite!

(s. 78)

Antonius

Yaklaş şuraya, seni kerata!

Adıvar, H. E. \& Urgan, M. (1949) s. 85

$\mathrm{Bu}$ söylemdeki "kite" göstergesi Antonius'un kızgın olduğu bir an Kleopatra için kullanılmıştır. Bu sözcüğün Oxford Online Sözlük'te çeşitli anlamları çıkmakta, özgün esere en çok uyan anlamı ise leşle beslenen "çaylak" hayvanı veya "sahtecilik işine bulaşmış"12 anlamıdır. Verilen çeviride ise "kerata" diye çevrildiğini görmekteyiz. "Kerata" sözcügüunü Türk Dil Kurumu'nun online sözlüğünde aradığımızda üç anlamı ile karşılaşmaktayız. İlk anlamı karısı tarafından aldatılan erkek; ikinci anlamı ayakkabı çekeceği; üçüncü anlamı ise küçük çocuklara sevgi ile söylenen bir sitem sözcüğü anlamları çıkmaktadır. Fakat bu çeviride ayakkabıyı giymede yardım eden araç veya sevimli çocuklar için söylenen sevgi dolu bir söz olmadı̆̆ı söylemden gayet açıtır zira Antonius, Kleopatra yüzünden savaşı kaybederek çok büyük bir hiddetle yükümsüz özneye dönüşerek bu kite sözcügünü kullanmıştır. Şunu not etmek ilginç olacaktır ki Antonius mevcut durumda karısı tarafından aldatılan bir adam konumundadır, fakat bu sözcük ile Kleopatra'yı çağırdığı için karısı tarafından aldatılan erkek anlamı da çımamaktadır. Bu söylemin çevirisinde Öztürk Kasar'ın (Öztürk Kasar \& Tuna 2015) özgün eserden tamamen bağıntısız olmayan ancak yanlış bir anlam üreterek çevirmek diye tanımladığı anlamın bozulması eğilimi vardır. Bu söylem diğer iki çeviride şöyle karşımıza çıkmaktadır:

Antonius

Hey, kim var orada? - Ah, seni akbaba!

Bozkurt, B. (2002) s. 142

Antonius

Hey, buraya gelin! Ah seni kahpe seni!

Eyüboğlu, B. (1967) s. 138

Bu iki çeviride "kite" sözcügü akbaba ve kahpe olarak çevrilmiş. Bozkurt (2002) bu söylem için dipnot düşerek "kite" teriminin kadınları aşağılamak için kullanılan bir terim olduğunu, "çaylak" kelimesinin Türkçede farklı çağrışımları olduğu için leş yiyen hayvan olan akbaba ifadesini yeğlediğini ifade etmiştir. Esenliksiz durumdan yükümsüz özneye dönüşen

12 http://www.oxforddictionaries.com/definition/english/kite. Erişim tarihi: 25.01. 2016 
Antonius'un Kleopatra'yı aşağılamak için bu sözbirimi kullandığını alımlayan Eyüboğlu (1967) ise kadınları aşağılamada Türkçede çok kullanılan "kahpe" sözcügünü tercih etmiştir. Bu iki çeviride söylemin anlam evreni yakalanarak Antonius'un yükümsüz özneye dönüştüğü gayet açık bir biçimde okura sunuluyorken, Edib-Adıvar \& Urgan'ın (1949) çevirisindeki "kerata" söylemin içindeki gösterge ile çok az ilintili olup anlamın bozulmasına sebep oluyor.

Örnek 7:

\section{SCARUS}

I had a wound here that was like a ' $\mathrm{t}$ ',

But now 'tis made an 'h'.

We'll beat 'em into bench-holes. I have yet

Room for six scotches more. (s. 90)

Scarus

Şuramda T şeklinde bir yaram vardı,

Ama şimdi H’ye dönüştü.

Hepsini lağım çukurlarına dökeceğiz.

Benim daha sekiz kesiğe yerim var. Bozkurt, B. (2002) s. 165

Bu söylemde kültürel bir öğe ağır basmaktadır. Bir işleve indirgenmiş yükümsüz özneye dönüşen Scarus'un bu durumunu okura sezdirebilmek için $\mathrm{T}$ şeklindeki yaranın H'ye dönüşmesi göstergesinin kullanıldığı görülmektedir. T şeklinde bir yaranın oluşması için biri dikey diğeri ise yatay en az iki tane kılıç darbesi yenmesi gerekmektedir. Bu yaranın alt ucuna bir tane daha yatay kılıç darbesi indiğinde bu yaranın şekli yandan bakıldığında $\mathrm{H}$ harfi gibi görülebilir, anlaşıldığı üzere Scarus üç kılıç darbesi yemiş ancak kendini komutanına adadığı için ve halen savaşabileceğini göstermek için altı kılıç darbesine daha dayanabileceğini ifade ediyor. Yazar bu altı rakamını kullanırken "kedilerin dokuz canı vardır" diye bilinen kültürel bir yargıya atıfta bulunmuş olabilir. Üç darbe yedikten sonra da geriye altı canı daha kalmıştır. Özgün metinde hem $\mathrm{T}$ harfi şeklinde yaranın oluşması hem de $\mathrm{H}$ harfine dönmesi aynı zaman olarak anlatılmıştır, dolayısıyla bu üç darbenin üçünü de bu savaşta almıştır. Ancak Bozkurt (2002)“six" rakamını Türkçeye "sekiz" olarak çevirmiştir. Bazı kültürlerde kedilerin 7 canının olduğuna inanılır, ancak İngilizcede genellikle kediler 9 canlı olarak bilinir. Çevirmen bu söylemin çevirisinde T şeklindeki yaraların eskiden var olduğunu, bu savaşta sadece bir kılıç darbesi aldığ için İngiliz kültüründe kedilerin 7 canlı olarak düşünülerek sadece bir canının gittiğini, Türkçeye bunu uyarlarken de bizim kültürümüze göre 8 canının kalması gerektiğini düşünmüş olabilir. Bu duruma bir dip not da düşen çevirmen sadece yaranın nasıl $\mathrm{H}$ harfi gibi görünebileceğini açıklamıştır ancak niçin 8 rakamını kullandığını açıklamamıştır. Bozkurt'un (2002) bu söylemde yaraların oluşum 
zamanına dikkat etmeyerek sadece bir yara aldı gibi yorumlaması ve kültürel öğeyi aşırı yorumlaması sebebiyle Öztürk Kasar'ın (Öztürk Kasar \& Tuna 2015) sinıflandırmasına göre anlamın bozulması eğilimi görülmektedir. Tanımda da yer aldı̆̆ı gibi özgün eserdeki söylemle ilintili ancak göstergenin yanlış çevrilmesi söz konusudur. Bu sözce Edib-Adıvar \& Urgan (1949) tarafından şöyle çevrilmiştir:

\section{SCARUS}

Şu yaram gittikçe büyüyor ve şekil değiştiriyor.

Onları kirli çukurlara süreceğiz. Daha benim altı yaralık yerim var. Edib-Adıvar \& Urgan (1949) s. 110

Bu sözce Edib-Adıvar \& Urgan'ın (1949) çevirisinde "T" harfi şeklindeki yaranın "H” harfine dönüşmesi göstergesi yok edilerek çevrilmiştir. Özgün eserde iki kılıç darbesinin sonrasında gelen yeni bir kılıç darbesini, yani toplam üç kılıç darbesini okura sezdirmek için kullanılmış olan ve sonrasında "dokuz canlı" göstergesini alımlamaya yarayacak şekilde "altı yaralık yer" göstergesi kullanılmışken, bu çeviride okura Scarus'un üç kılıç darbesi aldığını söylemeden "yaram .....şsekil değiştiriyor" şeklinde çevrilmesi okurun daha bir kılıç darbesinde niçin üç canın birden gittiğini sorgulatabilir. Öyleyse çevirmen özgün eserdeki bir göstergeyi çevirmemiş, gösterge yokluğuna neden olmuştur. Bu durum Öztürk Kasar'ın (Öztürk Kasar \& Tuna 2015) sınıflandırmasına göre anlamın yok edilmesi eğilimine örnek gösterilebilir.

\section{Örnek 8:}

\section{ANTONY}

All is lost!

This foul Egyptian hath betrayed me:

My fleet hath yielded to the foe, and yonder

They cast their caps up and carouse together

Like friends long lost. Triple-turned whore! (s. 94-95)

\section{ANTONIUS}

Her şey bitti. Alçak Mısırlı kahpelik etti bana,

Donanmam düşmandan yana geçiverdi.

Şimdi orda, küllahlarını havaya firlatıp

Çümbüş ediyor hepsi kavuşan eski dostlar gibi.

Seni üç belgeli orospu seni! Eyüboğlu (1967) s. 169 
Evaluation of Antony and Cleopatra Game of Semiotic Analysis and Translation Turkish Translation Semiotics Perspective / S. Öztürk Kasar - M. Kuleli (p. 98-123)

\section{ANTONIUS}

Her şey bitti.

Bu alçak Mısırlı bana ihanet etti.

Donanmam düşmana teslim oldu.

Şimdi orada hep birlikte,

Ne zamandır ayrı kalmış dostlar gibi,

Başlıklarını havaya firlatıp eğleniyorlar.

Seni üç kere dönek aşifte! Bozkurt (2002) s. 173

Özgün metinde geçen "triple-turned whore" göstergesi Julius Caesar oyununa yapılan bir göndermedir. Antonius'un Kleopatra'ya kızgınlığından dolayı ürettiği bu sözcede esenliksiz durumdan kaynaklanan yükümsüz özneye dönüştüğü bir bölümdür. Eyüboğlu'nun (1967) çevirisinde "üç belgeli orospu"; Bozkurt'un (2002) çevirisinde ise "üç kere dönek aşifte" özgün eserdeki yükümsüz özne durumundaki Antonius'un sözcesinin metinlerarası ilişkisini korumuştur. Bozkurt (2002) bu sözceyi bir dipnot ile açıklamış ve Kleopatra'nın Pompeius, Julius Caesar ve Antonius ile aşk yaşayarak üçüne de ihanet ettiğine gönderme yapıldığını ifade etmiştir. Ancak Edib-Adıvar \& Urgan’ın (1949) çevirisi şöyledir:

\section{ANTONIUS}

Her şey mahvoldu! O murdar Mısırlı bana hıyanet etti. Donanmam düşmana teslim oldu. Orada külahlarını havaya atıp eski dostlar gibi zevk-ü sefa edip içiyorlar. Seni kaşarlanmış kahpe! Edib-Adıvar \& Urgan (1949) s. 116

“Triple-turned whore” göstergesi Edib-Adıvar \& Urgan'ın (1949) çevirisinde "kaşarlanmış kahpe" göstergesi ile karşıllık bulmuştur. Türkçede bir kadına "kaşarlanmış" nitelemesini kullanmak onun çok kişi ile birlikte olduğunu göstermek için kullanılır. Ancak özgün eserdeki metinlerarası gönderge olan Kleopatra'nın Pompeius, Julius Caesar ve Antonius'un üçüyle de ilişki yaşadığına dair gösterge bu çeviride kaybolmuştur. Edib-Adıvar \& Urgan'ın (1949) eksik bilgi vererek yetersiz bir anlam üretmesi sonucunda ortaya çıkan bu anlam bozucu eğilim Öztürk Kasar'ın (Öztürk Kasar \& Tuna 2015) tarafından anlamın eksik yorumlanması olarak isimlendirilmiştir.

Örnek 9:

\section{CLEOPATRA}

Where art thou, death?

Come hither, come! come, come, and take a queen

Worth many babes and beggars! (s. 111)

\section{KLEOPATRA}

Neredesin, ey ölüm? Gel buraya, gel. 
Antony And Cleopatra Oyununun Göstergebilimsel Çözümlemesi ve Çeviri Göstergebilimi Bakış Açısıyla Türkçe Çevirilerinin Değerlendirilmesi / S. Öztürk Kasar - M. Kuleli (98-123. s.)

Gel, gel de, nice bebeklere biçareye bedel

Şu kraliçeyi de al götür. (Bozkurt, 2002) s. 200

\title{
KLEOPATRA
}

Ölüm nerdesin? Gel buraya gel! gel de nice çocuğa ve dilenciye bedel bir kraliçeyi al. (Edib-Adıvar \& Urgan, 1949) s. 136

Kleopatra'nın ölmek için büyük bir arzu duyduğu ve yükümsüz özne olarak ürettiği bu söylemde yüzeysel olarak yorumlanırsa ölüme seslenirken kendi canının bir bebekten veya dilenciden daha değerli olmadı̆̆ını ifade etmektedir. Ancak söylemin biraz daha derin yapısına girdiğimizde, Bozkurt (2002) bu söylemin çevirisinde bir dipnotla ölümün en kolay bebekleri ve dilencileri alabildiğini söylemiştir. Bu yüzden bu söylemde Kleopatra artık ölüme çok yakın olduğunu, ölümün kolayca onu alabileceğini, ölüme karşı tamamen savunmasız olduğunu söylemektedir. Bozkurt (2002) "”worth many babes and beggars" cümlesini nice bebeklere biçareye bedel şu kraliçe" cümlesiyle çevirirken, Edib-Adıvar \& Urgan (1949) "nice çocuğa ve dilenciye bedel bir kraliçe” cümlesi kullanmıştır. Bu cümlelerden Kleopatra'nın kendini dilenci ve bebekler kadar ölüme savunmasız gördüğü anlaşılmaktadır, bu yüzden herhangi bir anlam bozucu eğilim görülmemiştir. Eyüboğlu'nun (1967) bu söylemi çevirisi şöyledir:

\author{
KLEOPATRA \\ Neredesin ölüm? Gel alsana beni, gelsene! \\ Bebeklerin, dilencilerin canından \\ Daha az mı değerli bir kraliçenin canı? (Eyüboğlu, 1967) s. 194
}

Eyüboğlu'nun (1967) bebeklerin, dilencilerin canından / daha az mı değerli bir kraliçenin canı” cümlesini kullanması, ölüme savunmasız olmadığını göstermemektedir. Ayrıca özgün eserde ve Bozkurt'un (2002) çevirisi ile Edib-Adıvar \& Urgan'ın (1949) çevirisinde kraliçe ile bebek ve dilencilerin ölüme karşı durumu eşit bir şekilde söylenirken, Eyüboğlu'nun (1967) çevirisindeki "daha az mı değerli kraliçenin canı" cümlesi kraliçenin ölüm karşısında durumunun bebek ve dilencilerden daha üstün konumda olduğunu düşündürebilir. Eyüboğlu'nun bu söylemi çevirisinde özgün metindeki anlam ile ilintili bir anlam vardır ancak bu anlam bozulmaya uğramıştır ve Öztürk Kasar'ın (Öztürk Kasar \& Tuna 2015) sınıflandırmasına göre anlamın bozulması eğilimine örnek gösterilebilir.

Örnek 10:

\section{CLEOPATRA}

I dreamed there was an Emperor Antony.

O, such another sleep, that I might see

But another such man! (s. 112)

Özgün söylemde yer alan "man” göstergesi Kleopatra tarafından Antonius için kullanılmıştır. Antonius öldükten sonra esenliksiz durumdaki yükümsüz özneye dönüşen ve Caesar'ın Roma'da halka zaferinin boyutunu göstermek için Kleopatra'yı sergileyecek olması 
Kleopatra'nın uzun süre yükümsüz özne durumunda söylem üretmesine sebep olmuştur. Kleopatra Roma halkına sergilenmekten kurtulmanın tek yolunu kendini öldürmekte bulmaktadır ve kendini öldürerek Antonius'a da kavuşacağını düşünmektedir. Bu söylemde Antonius'a kavuşmak istediği ve onun gibi güçlü bir erkek ile ölümden sonra beraber olmak istediği anlaşılmaktadır. Bu söylemin çevirileri şöyle yapılmıştır:

\section{KLEOPATRA}

Antonius adında bir imparator gördüm düşümde.

Ah öyle bir uyku uyusam da yine

Onun gibi bir erkek görebilsem bir daha. (Eyüboğlu, 1967) s. 196

\section{KLEOPATRA}

Rüyamda Antonius diye bir İmparator gördüm.

Ah, keşke aynı uykuyu bir daha uyusam da,

Böyle bir adamı bir daha görebilsem. (Bozkurt, 2002) s. 202

Eyüboğlu (1967) man” göstergesini "erkek" diye çevirirken, Bozkurt (2002) bu göstergeyi "adam" göstergesi ile Türkçeye taşımıştır. Bu söylemde Antonius'tan sevgilisi olarak bahseden ve onun erkeksi yanını ortaya çlkaran Kleopatra'nın Antonius'tan "adam” veya "erkek" diye bahsetmesi olağan bir durumdur. Ancak bu söylem Edib-Adıvar \& Urgan (1949) tarafından şöyle çevrilmiştir:

\section{KLEOPATRA}

Rüyamda bir imperator Antonius gördüm. Ah, yine öyle bir uykuya dalsam da onun gibi bir insan görebilsem. (Edib-Adıvar \& Urgan, 1949) s. 137

Bu ceviride özgün eserdeki "man” göstergesi insan” göstergesi ile karşıllk bulmuştur. İngilizcede "man" kelimesinin karşılıklarından biri "insan, insanoğlu" olarak karşımıza çlkmaktadır. Bu çevirideki "insan" kelimesi "man” göstergesinin muhtemel anlamlarından biri olmasına rağmen bağlam gereği sevgilisine kavuşmak isteyen ve ondan "imparator" diye bahseden bir kraliçenin "insan" değil "erkek, adam" anlamında "man" göstergesini kullanmış olması daha muhtemeldir. Edib-Adıvar \& Urgan'ın (1949) çevirisindeki bu anlam bozucu eğilim Öztürk Kasar'ın (Öztürk Kasar \& Tuna 2015) sınıflandırmasına göre anlamın kaydırılması olarak düşünülebilir zira çeviri metindeki bir kelime özgün eserdeki göstergenin muhtemel anlamlarından biri ancak bağlam gereği diğer anlamlarından biri olarak çevrilmesi gerekirken başka anlam üretilmiştir.

Örnek 11:

\section{CLOWN}

Truly, I have him: But I would not be the party that should desire you to touch him, for his biting is immortal; those that do die of it seldom or never recover. (s. 119) 
Antony And Cleopatra Oyununun Göstergebilimsel Çözümlemesi ve Çeviri Göstergebilimi Bakış Açısıyla Türkçe Çevirilerinin Değerlendirilmesi / S. Öztürk Kasar - M. Kuleli (98-123. s.)

\section{CLEOPATRA}

Give me my robe, put on my crown,

I have

Immortal longings in me. (s. 120)

$\mathrm{Bu}$ söylemin alımlanması için öncelikle söylemin üretilme şartlarını özetlemek gerekmektedir. Kleopatra hem Antonius'un ölümünden duyduğu acı hem de Caesar'ın kendisini Roma'da sergileyecek olmasından duyduğu endişe yüzünden oyunun son ana kesitinin neredeyse tümünde yükümsüz özne olarak söylem üretmektedir. Mevcut durumdan kurtulmanın tek yolunu ölüm olarak gören Kleopatra, kendini öldürebilmek için Mısırlı bir köylüden acıtmadan sokan ve zehiri ölümcül olan bir yllan istemiştir. Bu söylemdeki köylü getirdiği yılandan bahsederken yazar tarafından "him" adılı kullanılmıştır. Bu durum yılana bir cinsiyet yüklendiğini göstermektedir. Shakespeare, Macbeth isimli oyununda da "yllan" göstergesini kullandığı söylemlerde bu hayvanı Lady Macbeth'e benzetmek için ve onun kötü kişiliğini yansıtmak için yılan göstergesinden "she" adılıyla yararlanmıştır. Yani "yılan" göstergesi Shakespeare tarafindan oyunda anlam evrenini güçlendirmek için başvurulan bir metafordur. Mevcut söylemde de "him" adılı ile "yılan" göstergesine atıf yapılması bu söylemin çevirisinde de erkeklik bildiren bir dil kullanılması gereğini doğurmuştur. Ayrıca göze çarpan diğer bir durum da yılanın zehri için "ölümcül” anlamına gelen "mortal" değil "ölümsüz" anlamına gelen "immortal" göstergesinin kullanılmasıdır. Bu durum oyunun aynı kesitinde yer alan diğer bir söylemle açık hale gelmektedir. Cleopatra'nın özgün söylemdeki "I have / Immortal longings in me" söylemi Kleopatra'nın ölümü bir son olarak değil Antonius'a kavuşacağı sonsuzluk olan gördüğünü göstermektedir. Bu yüzden yllanın zehri için "immortal" (ölümsüz) nitelemesi yazar tarafından tercih edilmiş olabilir. Bu söylemin çevirileri şöyledir:

\section{KÖYLÜ}

Doğrusu burada ama, onu ellemenize razı olacak değilim; çünkü onun sokması ebedidir. Bundan ölenler nadiren veya hiçbir zaman iyileşmezler. (Edib-Adıvar \& Urgan, 1949) s. 146

\section{KLEOPATRA}

Esvabımı ver, tacımı giydir; içimde ebedi hasretler var. (Edib-Adıvar \& Urgan, 1949) s. 147

\section{KÖYLÜ}

Getirmesine getirdim de, bence ona dokunmasan iyi olur, sokuşu ebedidir çünkü; onun sokuşundan ölen zor iflah olur ya da hiç olmaz. (Bozkurt, 2002) s. 212

\section{KLEOPATRA}

Kaftanımı ver. Koy başıma tacımı;

Ölümsüz özlemleri var içimde. (Bozkurt, 2002) s. 214

Edib-Adıvar \& Urgan (1949) ve Bozkurt (2002) özgün eserdeki yılanın erkek adılıyla kullanılmış olmasını, Türkçede eril ve dişil adıllar olmamasına rağmen“ısırma” anlamına gelen "biting" fiilini eril bir yüklem olan ve aynı zamanda Türkçede sürüngenlerin ısırması için kullanılan "sokma" fiiliyle çevirmeleriyle ve ayrıca her iki çevirmenin de "immortal" 
sıfatını özgün eserde olduğu gibi “ölümsüz” sıfatı ile çevirmeleriyle herhangi bir anlam bozucu eğilim yaratmamışlardır. Bu çeviri metinlerin okuru, özgün metnin okurunda olduğu gibi hem yılanın erkeksi yönünü hem de bu yılanın zehri ile Kleopatra'nın ölümünün aslında ölümsüzlüğe götüreceğini alımlamış olur. Ancak bu söylem Eyüboğlu'nun (1967) çevirisinde söyle karşımıza çıkmaktadır:

\section{KÖYLÜ}

Getirdim ama doğrusu ben razı olamam el sürmenize; çünkü bir ısırdı mı, hiç şaşmaz öldürür, kurtulan hiç yok, ya da binde bir. (Eyüboğlu, 1967) s. 207

\section{KLEOPATRA}

Giydirin beni, tacımı koyun başıma.

Ölümsüz dünyaya can atıyor içim. (Eyüboğlu, 1967) s. 209

$\mathrm{Bu}$ çeviride ise yllanın özgün eserde olduğu gibi eril bir kimliği görülmemektedir. Bu durumda çevirmen özgün eserdeki bir söylemde bulunan gösterge için eksik bilgi vererek yetersiz bir anlam üretmiştir. Öztürk Kasar'ın (Öztürk Kasar \& Tuna 2015) sınıflandırmasına göre bu durum anlamın eksik yorumlanmasına örnek gösterilebilir. Ayrıca Eyüboğlu'nun (1967) bu söylemi çevirisinde "immortal" sıfatını "öldürür" olarak çevirmesi ve aynı alt kesitte yer alan bir diğer söylemde ise bu sıfatı "ölümsüz" olarak çevirmesi buradaki anlam evrenine ters bir durumdur. Bu çeviride Kleopatra’nın hem "ölüm” hem de “ölümsüzlük” istiyor olması mantığa ters düşmektedir. Çevirmen bu sıfatın çevirisinde sıfatın kendi anlamına zıt bir anlam üretmiştir ve bu durum Öztürk Kasar'ın (Öztürk Kasar \& Tuna 2015) sınıflandırmasına göre karşıt anlam üretilerek ortaya çıkan anlamın çarpıtılmasına bir örnek olarak gösterilebilir.

Örnek 12:

\section{CLEOPATRA}

I am fire and air; my other elements

I give baser life. (s. 120)

\section{KLEOPATRA}

Şimdi ateşle havayım ben yalnızca;

Öteki öğeleri aşağıda, yaşamda bırakıyorum. (Bozkurt, 2002) s. 214-215

\section{KLEOPATRA}

Ben ateş ve suyum, diğer unsurlarımı daha adi bir hayata terkediyorum. (Edib-Adıvar, 1949) s. 148

Bu söylemde Kleopatra artık ölüme çok yaklaştığını, en büyük özelliği olan kadınlığa dair içinde bir şey kalmadığını ifade etmektedir. Bunun için yazar özgün metinde ruhu olmayan her maddenin dört öğeden oluştuğu inancına bir gönderme yapmaktadır. Bunu "fire, air, other elements" göstergeleri ile anlamaktayı. Doğadaki maddelerin "ateş, hava, toprak, su" olmak üzere dört unsurdan oluştuğu inancına göre iki unsur verilmiş, diğer iki unsur ise "my 
Antony And Cleopatra Oyununun Göstergebilimsel Çözümlemesi ve Çeviri Göstergebilimi Bakış Açısıyla Türkçe Çevirilerinin Değerlendirilmesi / S. Öztürk Kasar - M. Kuleli (98-123. s.)

other elements” cümlesi ile okura bırakılmıştır. Bozkurt (2002)'un “öteki öğeler”, EdibAdıvar \& Urgan’ın (1949) “diğer unsurlar” göstergelerini kullanmaları özgün eserde olduğu gibi okurun diğer iki unsuru bularak Kleopatra'nın artık ruhsuz bir madde gibi hissettiğini anlaması gereği ortaya çıkmıştır ve herhangi bir anlam bozucu eğilim görülmemektedir. Eyüboğlu'nun (1967) bu söylemi çevirisi şöyledir:

\section{KLEOPATRA}

Ben artık ateş ve hava olmak üzereyim:

Toprağı ve suyu daha aşağılık bir hayata bırakıyorum. (Eyüboğlu, 1967) s. 210

"Ates, hava" göstergelerinden sonra özgün eserde "my other elements" diye verilen gösterge Eyüboğlu (1967) tarafindan "toprağı ve suyu” göstergeleri ile çevrilerek özgün metin okuruna üstü kapalı verilen bir anlatımın çeviri metin okuruna açıkça verildiği ve bu çeviri metin okurunun diğer iki unsuru bulmasına hiç gerek kalmaksızın Kleopatra'nın ruhsuz bir maddeye dönüştüğünü anlamasına sebep olmuştur. Bu durum Öztürk Kasar'ın (Öztürk Kasar \& Tuna 2015) sinıflandırmasına göre anlamın aşırı yorumlanmasına örnek olarak gösterilebilir.

Örnek 13:

\section{CHARMIAN}

O, come apace, dispatch, I partly feel thee. (s. 122)

\section{CHARMIAN}

Hadi, çabuk ol, yap işini. Hissetmeye başladım bile seni. (Bozkurt, 2002) s. 217

\section{CHARMIAN}

Haydi çabuk ol, çabuk bitir, seni hissetmeğe başladım. (Edib-Adıvar \& Urgan, 1949) s. 149

Kleopatra ölünce hanımını kaybetmesinden dolayı tutkular türündeki içkin bileşenden kaynaklanan esenliksiz durumda yükümsüz özneye dönüşen Kharmian, Kleopatra ile aynı ölümü seçerek o da Caesar’ın adamları gelmeden yılanın zehri ile kendini öldürmek ister. Bunun için hızlı bir biçimde ölmek ister ve yılan ile konuşmaya başlar. Onu anlamayacak olan yılan ile konuşuyor olması yükümsüz özne olduğunu doğrulamaktadır. Bu söylemdeki "I partly feel thee" cümlesi Bozkurt (2002) tarafından "hissetmeye başladım bile seni" cümlesi ile, Edip-Adıvar \& Urgan (1949) tarafindan "seni hissetmeğe başladım" cümlesi ile çevrilmiştir. Bu söylemini incelediğimiz iki çevirisinde herhangi bir anlam bozucu eğilim bulunmamıştır. Ancak Eyüboğlu (1967) söz konusu söylemi şöyle çevirmiştir:

\section{KHARMIAN}

Aman, çabuk ol, pek acıtmadın bile ... (Eyüboğlu, 1967) s. 212

Bu çevirideki "pek acıtmadın bile" cümlesi özgün metindeki "partly" ifadesi sebebiyle diğer iki çeviriden farklı bir anlam katarak çevrilmiştir. "Partly" kelimesi Türkçede "kısmen" kelimesinin karşılığı iken özgün eserdeki gibi "feel" yüklemi ile birlikte bir bağlam oluşturduğunda "yavaştan hissetmeye başlamak" anlamı katmaktadır. Bu çevirideki "pek acıtmadın bile" cümlesi Kharmian'ın yükümsüz özne olarak bu söylemi üretmiş olmasına 
Evaluation of Antony and Cleopatra Game of Semiotic Analysis and Translation Turkish Translation Semiotics Perspective / S. Öztürk Kasar - M. Kuleli (p. 98-123)

aykırı bir durumdur zira kendini öldürmek isteyen ve o anda yaptıklarının ve söylediklerinin bilincinde olmayan bir yükümsüz öznenin acı hissetmesi veya hissetmemesi söz konusu olamaz. Bu durumda Eyüboğlu'nun (1967) bu söylemi çevirisinde yükümsüz öznenin söylemine uygun düşen bir cümle değil, tam aksine yükümsüz öznenin bilinçli olduğunu gösteren bir cümle kurulmuştur. Çevirmen bu cümle ile özgün eserdeki söyleme ilintili ancak yanlış bir anlam üretmiştir. Bu eğilim, Öztürk Kasar'ın (Öztürk Kasar \& Tuna 2015) sınıflandırmasına göre anlamın bozulmasına bir örnek olarak gösterilebilir.

\section{Sonuç}

Bulgular bölümünde yer alan çözümleme sonuçlarına göre Antony and Cleopatra oyununda çok sayıda yükümsüz özne saptanmış, ancak bunlardan rastgele seçilen 7 örnek burada gösterilmiştir. Bu oyunda saptanan yükümsüz özneye dönüşen öznelerin çoğunlukla temel bileşen ve tutkular türündeki içkin bileşenin etkisi altında söylemlerini ürettikleri bulunmuştur. Çeviri değerlendirmesi bulgularının olduğu bölüm göstermiştir ki yükümsüz özne içeren söylemlerin çevirilerinde Öztürk Kasar'ın (Öztürk Kasar \& Tuna, 2015) Çeviride Anlam Bozucu Eğilimler sınıflandırmasına göre 13 söylemin Türkçe çevirilerinde anlam bozucu eğilimler bulunmuştur. Bu anlam bozucu eğilimlerin beşianlamın bozulması, üçü anlamın kaydırılması, ikisi anlamın aşırı yorumlanması, diğer ikisi anlamın çarpıtılması ve biri anlamın eksik yorumlanması olarak sınıflandırılmıştır. Çözümleme bulgularından, bu anlam bozucu eğilimlerin oyun üzerinde bir göstergebilim çözümlemesi yapılmadan çevirilerin yapılmış olmasından kaynaklandığ 1 düşünülebilir. Edebiyat öyle kaygan bir zemin üzerine oturtulur ki yazar her şeyi söylemeksizin, söylemler yoluyla okura alımlaması için boşluklar bırakır ve göstergelerarası okuma yapan okur, yazarın bıraktı̆̆ı boşlukları doldurabilir. Tıpkı okurun yapacağı gibi, çevirmen de çevireceği yazınsal yapıta yönelik bir göstergebilim çözümlemesi yaptığında yazarın bıraktığı boşlukları doldurabilir, aksi takdirde özgün metinde yer alan örtük anlamlar çeviri metin okuru için kaybolur ve çeviri metin okuru özgün metin okuru ile aynı edebi hazzı yakalayamayabilir. Çeviri öncesi çevirmenin yaptığı bir göstergebilim çözümlemesi, çevirmenin anlam bozucu eğilimler olmaksızın metni hedef dile taşımasını sağlayabilir. Bu yüzden çevirmen adaylarına, yazınsal bir yapıtın çevirisi için öncelikle göstergebilim çözümlemesi yapmayı öğretilerek yazınsal yapıt çevirisinde pek çok zorluğu aşmalarında yardımcı olunabilir. Çevirmenler bir metni çevirmenin sadece kaynak dil kültürü ile hedef dil kültürü arasındaki bir geçiş olmadığını, aynı zamanda yazınsal yapıt yazarının bıraktığı boşlukları da hedef dil okuruna taşıyabilmek olduğunu bilmelidirler. Metin üzerinde göstergebilim çözümlemesi yapmak sadece çevirmenlere ve okurlara değil, çeviribilim alanı ile akademik olarak ilgilenen araştırmacılara da yardımcı olabilir. Biz de bu kapsamda, üretilmiş çevirilere göstergebilim penceresinden bakarak, çevirmenlerin içlerinde işlemesine engel olamadıkları anlam bozucu eğilimleri değerlendirmeye çalıştık. Bu tür çalışmaların, çeviri eğitiminde çevirmen adaylarına yararlı olacağını ve onların ilerde yapacakları yazınsal çevirilerdeki yetkinliklerini arttıracağını düşünüyoruz.

\section{Kaynakça}

Benveniste, E. (1995). Genel Dilbilim sorunları. (E. Öztokat, Çev.) İstanbul: Yapı Kredi

Coquet, J. C. (2007). Phusis et logos: Une phénoménologie du langage. Paris: PUF.

Coquet, J. C. (1997). La quête du sens: Le langue en question. Paris: Presses Universitaires de France-PUF.

Coquet, J.-C. (1984). Le Discours et son sujet. Paris: Klincksieck. 
Coquet, J.-C. ve Öztürk Kasar, S. (2003). Söylem, Göstergebilim ve Çeviri. İstanbul: Yıldız Teknik Üniversitesi.

Karantay, S. (1995). Tiyatro çevirisi: oyun dili ve çevirisi. Mehmet Rifat (Ed.), Çeviri ve çeviri kuramı üstüne söylemler. (ss. 93-115). İstanbul: Düzlem.

Merleau-Ponty, M. (2006).Algının Önceliği ve Onun Felsefi Sonuçları. (Y. Yıldırım, Çev.)İstanbul: Kabalcı.

Merleau-Ponty, M. (2005).Algılanan Dünya. (Ö. Aygün, Çev.) İstanbul: Metis.

Merleau-Ponty, M. (1964)Signs.Chicago: Northwestern University Press.

Merleau-Ponty, M. (1962).Phenomenology of Perception. (C. Smith, Çev.) London, New York: Routledge.

Öztürk Kasar, S. (2012). Jean-Claude Coquet ile bir dil görüngübilimine doğru. XII. Uluslararası Dil, Yazın ve Deyişbilim Sempozyumu Bildiriler Kitabiiçinde. (ss. 427433). Edirne: Trakya Üniversitesi

Öztürk Kasar, S. (2009) « Pour une typologie des non-sujets: au carrefour de la sémiotique et de la phénoménologie. »Sémio 2007: Rencontres sémiotiques: les interfaces disciplinaires, des théories aux pratiques professionnelles. Actes duCongrès international de l'Association Française de Sémiotique, Paris : Université Paris IV La Sorbonne. http://afssemio.com/semio2007/spip.php?article19. s. 3-6

Öztürk Kasar, S. ve Tuna, D. (2015). Yaşam, Yazın ve Yazın Çevirisi İçin Gösterge Okuma. Frankofoni Ortak Kitap, 27. 457-482.Ankara.

Primozic, D.T. (2013) Merleau-Ponty üzerine. (Z. Esenyel, Çev.) Bursa: Sentez.

Rozemond, M. ve Rozemond, M. (2009). Descartes's dualism. Cambridge: Harvard University Press.

Saussure, D. (2001). Genel dilbilim dersleri. (B. Vardar, Çev.) İstanbul: Multilingual

Shakespeare, W. (1950). Antony and Cleopatra. Cambridge: University Press.

Shakespeare, W. (2002). Antonius ve Kleopatra. (B. Bozkurt, Çev.) İstanbul: Remzi.

Shakespeare, W. (1967). Antonius ve Kleopatra. (S. Eyüboğlu, Çev.) İstanbul: Remzi.

Shakespeare, W. (1949). Antonius ve Kleopatra. (H.E. Adıvar ve M. Urgan, Çev.) İstanbul: Pulhan.

http://www.oxforddictionaries.com/definition/english/kite. Erişim tarihi: 25.01. 2016

http://dictionary.cambridge.org/dictionary/turkish/command_1 Erişim tarihi: 20.12.2015

http://dictionary.cambridge.org/dictionary/turkish/man_1. Erişim tarihi: 08.12. 2015

http://tdk.gov.tr/index.php?option=com_gts\&arama=gts\&guid=TDK.GTS.5656eaa3b40f19. 99706079 Erişim tarihi: 25.11.2015 